http://jmscr.igmpublication.org/home/

ISSN (e)-2347-176x ISSN (p) 2455-0450

crossref DOI: https://dx.doi.org/10.18535/jmscr/v8i11.38

Journal Of Medical Science And Clinical Research

\title{
A Clinical Study of Acute Scrotal Swelling
}

\section{Dr G. Balasubramanian, ${ }^{1}$ Dr R.Ramesh, ${ }^{2}$ Dr K.Ravichandran, ${ }^{3}$ Dr R. Jayaraman ${ }^{4}$ \\ ${ }^{1}$ Junior Resident, ${ }^{2}$ Professor and HOD, ${ }^{3}$ Associate Professor, ${ }^{4}$ Assistant Professor,}

Department of General Surgery, Rajah Muthiah Medical College \& Hospital, Annamalai University, Tamil

Nadu, India

\begin{abstract}
Background and Objectives: Acute scrotal swelling is a group of heterogeneous disease of the scrotal organs, that have a similar clinical picture and which may require surgical treatment.

Aim: To study the clinical presentation, differential diagnosis, and management of different acute scrotal condition.

Material And Methods: A prospective study was conducted 100 patients among aged between 13-70 years, presenting with acute scrotal swelling. After obtaining ethical committee approval, the study was conducted among the patient who presented with acute scrotal swelling with informed written consent from the patient.

Results: Epididymo-orchitis was found in 48 out of 100 patients and torsion of testis (17), Epididymoorchitis was found to be common clinical condition followed by torsion of testis which occurs in younger individual. Scrotal swelling associated with pain was the most common presenting feature, where fever and urinary symptoms being most common feature in epididymo-orchitis. Haemogram, urine analysis were not conclusive but supportive to clinical diagnosis. Ultrasound of scrotum was $92.58 \%$ sensitive and $100 \%$ specific.

The period of hospitalisation was found to be more in fournier's grangrene (mean 25 days.) rather than epididymo-orchitis

Conclusion: In our study shows acute epididymo-orchitis found to be commonest condition followed by torsion of testis. Testicular torsion is a true surgical emergency which required careful examination, proper evalution and prompt treatment with early surgical management.

Keywords: Acute scrotum, torsion of testis, epididymo-orchitis, fourniers gangrene.
\end{abstract}

\section{Introduction}

Acute scrotal swelling is an acute painful swelling of the scrotum, which is the most common cause of admission to the emergency department. Testicular torsion and infection are most common cause of acute scrotal swelling. Infection is more common in adults while testicular torsion is more common in younger individual. The syndrome of edematous scrotum means acute diseases accompanied by edema, hyperemia and pain in the area. The non infectious disease of acute scrotal condition like testicular tortion and traumatic injuries and infectious lesion includes epididymitis, orchitis, epididymo-orchitis, scrotal wall abscess and fourniers gangrene. Differential diagnosis is necessary for choosing the right treatment tactics and maintaing the patients fertility in future. 


\section{Testicular Torsion}

Testicular torsion occur when a testicle rotates, twisting the spermatic cord that brings blood to the scrotum. Sudden onset of pain and swelling occurs after decrease in the blood flow of scrotal organ. Testicular torsion usually requiers surgical exploration. Testicular torsion is divided into two types, intravaginal and extravaginal torsion. When the testis twists within the tunica vagina is called intravaginal testicular torsion whereas extravaginal testicular torsion occurs in the perinatal period before fixation of the tunica vaginalis with in the scrotum. In our study the most common presentation of testicular torsion occurs between 13 and 25 years of age.

The complete viability of testis can be achieved if we release the torsion within the occurrence of 4 hrs. Up to 16 hours, $89 \%$ of testes can be salvaged but this decreases to $25 \%$ after 16 hours, however that surgery should always be an emergency procedure to confirm viability of testes. Acute epididymo-orchitis is an inflammation of the epididymis and testis. Its usualy due to infection, most commonly from the urinary tract and sexually transmitted infection. Fourniers gangrene; fourniers gangrene is a necrotizing infection of soft tissue which involve in deep and superficial fascia of the male genitalia.

\section{Objectives of the Study}

1. To conduct a prospective study of 100 patients from September 2018 to august 2020 with an aim, to conduct a clinical study of acute scrota swelling in patient visiting surgical OPD and casualty in the department of general surgery at Rajah Muthiah Medical College and Hospital, Annamalainagar Chidambaram.

2. To study the differential diagnosis and the cause of acute scrotum.

3. To study clinical presentation and management of different acute scrotal conditions.

\section{Materials and Methods}

A prospective study was conducted 100 patients among aged between 13-70 years. Presenting with acute scrotal swelling.

\section{Source of Data}

After getting the ethical committe approval, the study to be conducted among the patients who presented with acute scrotal swelling with informed written consent from the patient

\section{Method of Collection of Data:}

Clinical features, symptomatology, investigations, operative findings, post operative complications, were entered in the proforma and analysed. Histopathological examination was performed in two cases, one for torsion of testis and other for haematocele. A total of 100 patients were studied.

\section{Inclusion Criteria}

Age $>13$ years $<70$ years patient who gave consent, patients with comorbid condition like diabetes mellitus. All patients visiting in general surgery $\mathrm{OP}$ of $\mathrm{RMMCH}$ with acute scrotal swelling.

\section{Exclusion Criteria:}

Children $<13$ years, $>70$ years patient with chronic scrotal disease

\section{Results and Discussion}

The study consists of analysis of 100 patients of acute scrotal swellings admitted in the department of general surgery at Rajah Muthiah Medical College and Hospital, Annamalainagar Chidambaram.

1. Incidence of various types of lesions:

The incidence of various conditions which led to acute scrotum were found as follows.

Table-1: Incidence of lesions

\begin{tabular}{|l|c|c|c|}
\hline $\begin{array}{l}\text { S. } \\
\text { No. }\end{array}$ & Lesion & $\begin{array}{c}\text { No. of } \\
\text { patients }\end{array}$ & Percentage \\
\hline 1. & Epididymo-orchititis & 48 & $48 \%$ \\
\hline 2. & Torsion of testis & 17 & $17 \%$ \\
\hline 3. & Orchitis & 10 & $10 \%$ \\
\hline 4. & Epididymitis & 6 & $6 \%$ \\
\hline 5. & Pyocele & 7 & $7 \%$ \\
\hline 6 & Scrotal wall abscess & 4 & $4 \%$ \\
\hline 7. & Fourniers gangrene & 3 & $3 \%$ \\
\hline 8. & Idiopathic scrotal edema & 2 & $2 \%$ \\
\hline 9. & Haematocele & 2 & $2 \%$ \\
\hline 10. & Testicular abscess & 1 & $1 \%$ \\
\hline & Total & 100 & $100 \%$ \\
\hline
\end{tabular}


In our study acute epididymo-orchitis (48\%, $\mathrm{n}=48$ ) was the commonest cause of acute scrotal pathology followed by torsion of testis (17\%, $\mathrm{n}=17)$. Incidence of orchitis $10 \% \quad(\mathrm{n}=10)$, epididymitis $6 \%(\mathrm{n}=6)$, pyocele were $7 \%(\mathrm{n}=7)$, $4 \%(n=4), 2 \%(n=2), 1 \%(n=1)$ respectively. 3 cases of fourniers gangrene (3\%) were also found. Abul F, Al-Sayer H, Arun $\mathrm{N}$ in a review of 40 acute patients hospitalized for acute scrotum showed that the most common etiology of acute scrotal edema was epididymitis $(60 \%)$. This was followed by testicular torsion, torsion of the appendages and acute idiopathic scrotal edema in $27.5 \%, 10 \%$, and $2.5 \%$, respectively.

In comparison with the above study where the most common cause of acute scrotal swelling was epididymitis; in our study it was found to be acute epididymo-orchitis (48\%) followed by torsion of testis (17\%), orchitis (10\%), epididymitis $(6 \%)$, pyocele $(7 \%)$, fourniers gangrene $(3 \%)$, haematocele $(2 \%)$ and scrotal wall abscess (4\%).

\section{Incidence of Age:}

Table 2 Incidence of Age

\begin{tabular}{|l|c|c|}
\hline Age in year & No. of patients & Percentage \\
\hline $13-20$ & 18 & $18 \%$ \\
\hline $21-30$ & 13 & $13 \%$ \\
\hline $31-40$ & 14 & $14 \%$ \\
\hline $41-50$ & 19 & $19 \%$ \\
\hline $51-60$ & 24 & $24 \%$ \\
\hline $61-70$ & 12 & $12 \%-$ \\
\hline Total & 100 & $100 \%$ \\
\hline
\end{tabular}

The overall age incidence is shown in table. The maximum incidence occured between the age group of 51-60 years. Teoman Eskitaşcıoğlu et al [2014] stated that the age of the patients ranged from 19 to 82 years, and the mean age of $53.5 \pm 13.6$ years in their study with the high- est incidence of FG observed in the age group of 5060 years $(n=25,31.25)$. Ruiz-Tovar J et al [2013] reported a mean age of $57.9 \pm 13.5$ years in the study of seventy patients. In our study the age incidence for acute epididymo-orchitis was highest in between 51 to 60 year of age where torsion of testis was 13-20, mean being 58.07 yrs for acute epididymo-orchitis and 16.125 yrs for torsion of testis. In comparison with other studies, our study showed early age of presentation for torsion of testis \&advanced age for acute epididymo-orchitis.

Table 3: Incidence of Occupation

\begin{tabular}{|l|c|c|}
\hline Occupation & $\begin{array}{c}\text { No. of } \\
\text { patients }\end{array}$ & Percentage \\
\hline $\begin{array}{l}\text { Manual Labourer } \\
\text { (Agri, coolie, driver etc) }\end{array}$ & 68 & $68 \%$ \\
\hline $\begin{array}{l}\text { Sedentary student, } \\
\text { (Teacher, } \\
\text { Engineer, clerk etc.) }\end{array}$ & 32 & $32 \%$ \\
\hline Total & 100 & $100.00 \%$ \\
\hline
\end{tabular}

Acute scrotal swellings were found to be more common in people who were subjected to strenous work, involving manual labourers like farmers \& labourers. In a series of 68 cases, $68 \%$ of case were manual labourers. Only $32 \%$ cases were sedentary workers such as students, clerks etc.

\section{Duration of symptoms}

Table 4 Duration of Symptoms

\begin{tabular}{|c|c|c|}
\hline Duration & No. of patients & Percentage \\
\hline $0-24$ hr. & 28 & $28 \%$ \\
\hline $1-7$ days & 54 & $54 \%$ \\
\hline $8-15$ days & 18 & $18 \%$ \\
\hline $16-30$ days & - & - \\
\hline$>30$ days & - & - \\
\hline Total & 100 & $100 \%$ \\
\hline
\end{tabular}

4.Duration of symptoms varied from few hours to as long as 15 days. The shortest duration of symptoms in this study was 12 hours \& longest duration was two week. The average duration of pain from onset till presentation in case of epididymo-orchitis was 5 days, where as it was 4 days in a study conducted by Ricardo et al. The average duration of symptoms from onset till presentation in case of torsion of testis was $24 \mathrm{hrs}$ in our study. 
5.Predisposing factors

Table 5- History of predisposing factor

\begin{tabular}{|l|c|c|}
\hline History & No. of patients & Percentage \\
\hline Trauma & 12 & $12 \%$ \\
\hline $\begin{array}{l}\text { Urinary } \\
\text { symptoms }\end{array}$ & 35 & $35 \%$ \\
\hline $\begin{array}{l}\text { Similar } \\
\text { complaints in the } \\
\text { past }\end{array}$ & 15 & $15 \%$ \\
\hline $\begin{array}{l}\text { Exposure to STD } \\
\text { Idiopathic }\end{array}$ & 18 & $18 \%$ \\
\hline Total & 100 & $20 \%$ \\
\hline
\end{tabular}

In a study conducted by Ricardo C. Del Villar of 45 cases, history of similar complaints in the past was found in 2 cases of epididymitis \& in 6 cases of torsion testis. Also there was history of trauma in 7 cases of epididymitis \& in 3 case of torsion testis. In this study, apart from the idiopathic cause which compromised $37.5 \%$ of the cases, the next most common cause was trauma in 7 cases $(21.8 \%)$. Dysuria was present in 7 cases of epididymitis and in 1 case of torsion.

Studies conducted by Arshad Mehmood Malik et al [2010] and B. Fall et al [2009] stated idiopathic cause in $32.8 \%$ and $25.5 \%$ cases respectively.

In our study, there was history of trauma in 10 cases of torsion of testis and in two case of haematocele. There was history of urinary symptoms in 32 cases of epididymo-orchitis \& in 3 case of epididymitis. Like other studies, majority of cases were iediopathic in origin $(42 \%$, $\mathrm{n}=21$ ).In our study the most important predisposing factors is UTI $(32 \%, \mathrm{n}=32)$ and trauma $(12 \%, \mathrm{n}=12)$.

\section{Presentation of cases}

Table 6 Presenting Symptoms

\begin{tabular}{|l|c|c|}
\hline Symptoms & No. of patients & Percentage \\
\hline Swelling & 100 & $100 \%$ \\
\hline Pain & 100 & $100 \%$ \\
\hline Fever & 46 & $46 \%$ \\
\hline Burning micturition & 35 & $35 \%$ \\
\hline Trauma & 12 & $12 \%$ \\
\hline Difficulty in passing urine & 4 & $4 \%$ \\
\hline Pain in Abdomen & 12 & $12 \%$ \\
\hline
\end{tabular}

All cases had swelling of scrotum, associated with pain at the time of presentation. $46 \%$ patients had history of fever while $35 \%$ patients had history of burning micturation. four patient had difficulty in passing urine, 12 patients had history of scrotal pain associated with pain in abdomen.

\section{Distribution of symptoms}

Table 7: Distribution of symptoms.

\begin{tabular}{|l|c|c|}
\hline Side & No of cases & Percentage \\
\hline Right & 58 & $58 \%$ \\
\hline Left & 30 & $30 \%$ \\
\hline Bilateral & 12 & $12 \%$ \\
\hline Total & 100 & $100 \%$ \\
\hline
\end{tabular}

In this study of 100 cases, it was observed that acute scrotal swelling was common on right side occuring for $58 \%$ case as compared to left side $(30 \%)$ Bilateral swelling were found in $12 \%$ of cases.

\section{Investigations}

For all 100 cases, routine investigations like haemogram and urine analysis were done. Blood urea \& Blood sugar levels were done in 58 cases. Special investigations like USG of scrotum was done in 100 cases.

The urine examination showed traces of albumin in 22 cases and sugar in 18 cases. Microscopic examination showed significant pus cells in 30 cases.

There was increase in total leucocyte count in 38 cases, showing acute infection. Thorsteinn Gislason showed that leucocytosis was present in $44 \%$ cases where as in our study it was $54.55 \%$.

There was increase in blood urea level in 2 cases of fourniers gangrene and 20 cases of epididymoorchitis was increased blood sugar level.

On ultrasonography, in case of acute epididymoorchitis, testis was diffusely hypoechoic and swollen. The epididymis was hyperechoic and swollen. In case of torsion of testis Testicular blood flow is visualized on the normal side but is absent on the affected side and the spermatic cord In case of testicular abscess, there was hypoechoic shadow in the test is showing collection of fluid. In case of pyocele, the echogenecity around 
the testis was not uniform showing purulent collection with thickened scrotal sac. A similar picture was found in haematocele. Hence it is difficult to differentiate haematocele from pyocele, ultrasonologically. In case of scrotal wall edema USG revealed a thickened scrotal wall.

\section{Treatment}

Table 8: Treatment

\begin{tabular}{|l|c|c|}
\hline Treatment given & No. of Patients & Percentage \\
\hline 1. Conservative & 64 & $64 \%$ \\
\hline 2. Surgical & 10 & $10 \%$ \\
\hline a. Incision \& drainage & 1 & $1 \%$ \\
\hline $\begin{array}{l}\text { b. Scrotal exploration with } \\
\text { drainage of testicular } \\
\text { abscess }\end{array}$ & 2 & $2 \%$ \\
\hline c. Debridement only & 8 & $8 \%$ \\
\hline $\begin{array}{l}\text { d. Multiple dibridement } \\
\text { followed by secondary } \\
\text { suturing dibridement }\end{array}$ & 4 & $4 \%$ \\
\hline $\begin{array}{l}\text { e. Multiple followed by skin grafting } \\
\text { follong with }\end{array}$ & 2 & $2 \%$ \\
\hline $\begin{array}{l}\text { f. Scrotal exploration evacuation of haematocele and } \\
\text { repair of testicular tear. }\end{array}$ & 14 & $14 \%$ \\
\hline g. Orchidectomy & & \\
\hline
\end{tabular}

\section{Conservative Treatment}

In this series of 100 cases, 64 cases (64\%) were managed conservatively. 48 cases of epididymoorchitis, ten cases of orchitis, six case of epididymiti and two case of scrotal edema were treated conservatively with rest,scrotal support, antibiotics and analgesics. Conservative treatment was given for 7 days to 21 days

\section{Surgical Treatment}

Scrotal exploration with drainage of testicular absess was done in 1 case. Incision and drainage of scrotal abscess was carried out in all cases. Out of 3cases of Fourneir's gangrene, only debridement was carried out in 2 patients. Multiple debridement followed by secondary suturing in 8 cases and skin grafting in 4 cases was carried out.

Scrotal exploration with evacuation of haematoma and repair of ruptured testis was carried out in 2 patients. Out of 17 cases of torsion testis, affected side orchidectomy and opposite side orchidopexy was carried out in 14 patient, remaining 3 cases were treated with detorsion of testis.

\section{Results of Treatment}

Patients treated conservatively responded well with complete recovery. In surgically treated patients, post operative recovery was uneventful in 41 cases with 5 cases developing wound infection as a complication. 2 patients of fourniers gangrene was expired on the same day of operation due to increased renal parameters and septicaemia.

The average hospital stay in patients with conservative treatment was 7.24 days. Patients with Fourneir's gangrene, the average hospital stay was 25.29 days. In other cases treated surgically, the average hospital stay was 10.42 days.

Follow up : All patients were followed up for period of one month to three months.

\section{Conclusion}

The primary objective of management of acute scrotum is to avoid testicular loss. Acute scrotal swellings are common in younger \& middle age individuals with variable symptomatology. These cases need careful examination, proper evaluation and prompt treatment. The likelihood of testicular salvage in torsion depends on the interval between onset of pain and surgical intervention. The commonest cause for acute scrotum is epididymoorchitis followed by torsion of testis. Routine investigation like urine analysis, haemogram, blood sugar, urine $\mathrm{C} / \mathrm{S}$, Wound swab $\mathrm{C} / \mathrm{S}$ and special investigations like USG scrotum are not always very much conclusive to the final diagnosis but are supportive to clinical diagnosis. Conservative treatment with rest, scrotal support, antibiotics and analgesics are effective in case of epididymo-orchitis. Emergency surgical exploration proved to be the best in case of Torsion testis, Fournier's gangrene, pyocele \& haematocele. 


\section{Reference}

1. Acute disease of the scrotum(acute scrotal syndrome) author; lorenzo E. derchi, michele bertolotto, massimo valentino 21.12.2017

2. Department of planned surgery and urology-andrology morozovskaya childrens city clinical hospital of moscow

3. William C S.Acute scrotal pathology. Surg C 1 N America 1982; 62 (6) : 955- 970

4. Williamson R C N. Torsion of the Testis and Allied Condition. Br J Surg 1976; 4. 63: $465-476$

5. Julia Spencer Barthold, MD. Campbell's Urology. 10th edition.Philadelphia: Saunders; 2012 p.3587-3594

6. Baglaj M, Carachi R. Neonatal bilateral testicular torsion: a plea for emer- gency exploration. J Urol 2007;177(6):2296-9

7. Watkin, N.A., Reiger, N.A., and Moisey, C.U. (1996) Is the conservative management of the acute scrotum justified on clinical grounds? Br. J. Urol. 78, 623-627

8. Tracy CR, Steers WD, Costabile R. Diagnosis and management of epididymitis. UrolClin North Am 2008;35:101-8

9. B. Klin, L. Zlotkevich, T. Horne, Y. Efrati, F. Serour and G. Lotan, "Epididymi- tis in Childhood: A Clinical Retro- spective Study Over 5 Years," The Israel Medical Asso- ciation Journal, Vol. 3, No. 11, 2001, pp. 833-855

10. J. Ben Chaim, I. Leibovitch, J. Ramon, D. Winberg and B. Goldwasser, "Etiol- ogy of Acute Scrotum at Surgical Ex-ploration in Children, Adolescents and Adults," European Urology, Vol. 21, No. 1, 1992, pp. $45-47$

11. Viswaroop BS, Kekre N, Goplalkrishnan G. Isolated tuberculous epididymi- tis:a review of 40 cases. J Postgrad Med 2005;51(2):109-111
12. Yan-Dong Li, Wei-Fang Zhu, Jian-Jun Qiao, Jian-Jiang Lin. Enterostomy can decrease the mortality of patients with Fournier gangrene. World J Gastroenterol 2014 June 28; 20(24): 7950-7954

13. Bisno AL, Stevens DL. "Streptococcal infections of skin and soft tissue" North En gland Journal of Medicine 1996, 334: 240-5

14. Patriquin HB, YazbeckS, Trinh B et al. Testicular torsion in infants and chil- dren: diagnosis with Doppler sonography. Radiology 1993; 188(3): 781 - 5

15. Abul F, Al-Sayer H, Arun N: The acute scrotum: a review of 40 cases. Med Princ Pract 2005; 14: 177-81

16. Lloyd J Peterson, Whitlock N W, Odom R B, Ramirez R E, Stutzman R E,M- caninch J W. Bilateral Fat Necrosis of the scrotum. J Urol 1976 ; 116 : 825- 826.

17. Teoman Eskitaşcioğlu, , İran Özyazgan., Atilla Coruh et al. Experience of 80 cases with Fournier's gangrene and "trauma" as a trigger factor in the etiopathogenesis. Turkish journal of trauma \& emergency surgery: TJTES(Im- pact Factor: 0.34). 07/2014; 20(4): 265-274. DOI: 10.5505/tjtes.2014.67670

18. Ruiz-Tovar J, Córdoba L, Devesa JM. Prognostic factors in Fournier gangrene. Asian J Surg. 2012 Jan; 35(1): 37-41

19. Ricordo G. Del Villar, Ireland G W, Cass A S. Early Exploration in acute testic- ular conditions. J Urol 1972; 108 : 887-888

20. Arshad Mehmood Malik, Shiraz Sheikh, Asad Khan, Ubedullah Sheikh. The spectrum of presentation and management of Fournier's gangrene an expe- rience of 73 cases. PMA.org.pk/full_article_text.php?article_i $\mathrm{d}=2216$. Au- 